\title{
Obituaries
}

\section{PROFESSOR THOMAS PITT FORD}

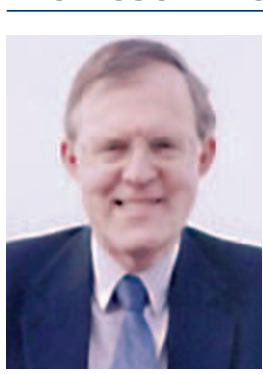

Tom Pitt Ford, Professor of Endodontology, Director of Education and Vice Dean of the Dental Institute for King's College London, died peacefully at home in the early

hours of Sunday 17 August.

Tom qualified from Guy's Hospital Dental School in 1971 with honours in prosthetic dentistry and went onto gain his FDS from Glasgow and his PhD from the University of London in 1980. He was latterly awarded the FDS from both Edinburgh and London in honour of his contributions to endodontology.

He was a major figure in endodontology, internationally known for his work and widely published. As editor of the International Endodontic Journal, Tom made a significant contribution to enhanced scientific rigour in the field. He was appointed to Chair in Endodontology at United Medical and Dental Schools in 1997, the first in the UK.

His attention to detail was legendary and his superb administration resulted in the Dental School scoring a maximum 24 out of 24 in the National Teaching Exercise. In 2002 he was appointed Director of Education in the merged King's College London Dental Institute. His leadership qualities were recognised by his appointments as Vice Dean, as Chair of the KCL Education Committee, and as Director of Institutional and Academic Audit for the College. He was awarded the Dental Alumnus Distinguished Service Award in 2008 in honour of his contribution to the Dental Institute.
His major legacy, however, will be his contribution to the development of British and International endodontology, his extensive writing and his scholarship and journal editorship. Uniquely he was elected twice as President of the British Endodontic Society. Largely due to Tom, endontolology is now a well established specialty in the UK

Tom's death is a great loss not only to his family, but also to his colleagues at KCL Dental Institute and the dental academic world. His influence and example will survive him, but he will be sorely missed. He has been superbly supported by his wife, Heather, and three children Alexandra, Charles and Edward, throughout his illustrious career.

S. Challacombe

\section{CELIA ROSS}

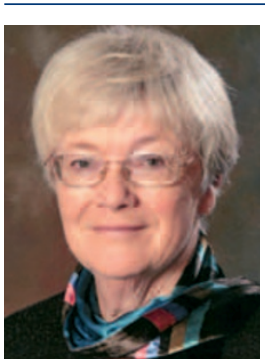

Celia died on 13 June 2008 aged 67, after a brave battle against cancer. She fought her illness with the energy, determination and inquiring mind that characterised both her professional and private life. One of life's 'doers', she researched possible treatments for her condition, whilst still undertaking all her professional commitments until very shortly before she died.

Celia graduated from Birmingham Dental School in 1963 and became their first female house officer in oral surgery. Her yearn for travel led her to Uganda as one of the first VSO dentists. Qualified for barely a year, she was designated Consultant in Oral Surgery, but she learnt fast. Forty years later she returned to work in
Uganda for Dentaid, for whom she was a stalwart fundraiser.

Having married Michael Ross, they moved to New Zealand where she taught prosthetics at Otago Dental School, and then to Fiji, where motherhood prompted a move into general practice. Coming back to the UK Celia settled into general practice, owning a series of practices in High Wycombe, and then in Great Missenden. Being a self-confessed 'gadget freak', her practices always boasted the latest equipment, but her care for her patients was equally of the best and staff and patients stayed with her for many years.

Celia devoted much of her time to serving her colleagues in the BDA and on Buckinghamshire LDC. The Department of Health appointed her the first Chairman of the Dental Vocational Training Authority. She was awarded the coveted Fellowship of the BDA in 2006 and was a founder-member of Women in Dentistry.

Celia lived life to the full. After an amicable divorce, she met Don who shared her love of travel, and who became her devoted partner. The BDJ study trips of the mid-1980s saw her as a regular participant, and with a trip to Antarctica in 2007 she reached her goal of visiting every continent. Her other hobbies were skiing and windsurfing, plus an overall passion for horses.

At her funeral Great Missenden church was packed with friends and colleagues from across the country. The sunshine, and bright clothes she requested to be worn, served to emphasise the fun and friendship she radiated to all throughout her life. Our sympathies are extended to Don, her children Kate and Jon, and the grandchildren of whom 'horsey granny' was very proud.

Stephanie Twidale, Dame Margaret Seward 